\title{
Importance and Perception of the Character Strengths Scale: psychometric evidence in professors
}

\section{Escala de Importancia y Percepción de Fortalezas Personales: evidencias psicométricas en profesores}

\section{Escala de Importância e Percepção das Forças de Caráter: evidências psicométricas em professores}

\author{
Valeschka Martins Guerra', ORCID 0000-0001-7455-125X \\ Leogildo Alves Freires ${ }^{2}$, ORCID 0000-0001-5149-264 \\ Clarisse Lourenço Cintra ${ }^{3}$, ORCID 0000-0001-6746-1934 \\ Marcella Bastos Cacciari, ORCID 0000-0003-2018-2262 \\ Naiara Ferreira Vieira Castello ${ }^{5}$, ORCID 0000-0003-2820-5617 \\ 1345 Universidade Federal do Espírito Santo, Brazil \\ ${ }^{2}$ Universidade Federal de Alagoas, Brazil
}

\begin{abstract}
This study aimed at presenting the development and psychometric evidence of the Importance and Perception of Character Strengths Scale (IPCSS)-Professor Version. Two quantitative studies were conducted. In Study 1 the respondents were 214 college professors (mean age $=39.21 ; S D=9.77 ; 55.6 \%$ females), who answered the IPCSS-Professor and sociodemographic questions. Exploratory analysis suggested a one-factor structure for both subscales. Respondents in Study 2 were 262 college professors (mean age $=41.80 ; S D=9.81$; $50.8 \%$ male). Confirmatory factor analysis suggested the adequacy of the six-factor structure theoretically proposed for both subscales after comparison with the alternative single-factor model. The IPCSS-Professor presented satisfactory reliability indexes and it is applicable for teachers of different sectors in order to understand their character strengths.
\end{abstract}

Keywords: character strengths; virtues; positive psychology; scale; professors

Resumen: Este estudio tuvo como objetivo presentar el desarrollo y la evidencia psicométrica de la Escala de Importancia y Percepción de Fortalezas Personales (IPCCS, por su sigla en inglés)Versión Profesores. Se realizaron dos estudios cuantitativos. En el Estudio 1, los encuestados fueron 214 profesores universitarios (edad media $=39.21 ; D E=9.77 ; 55,6 \%$ mujeres), que respondieron al IPCSS-Profesor y preguntas sociodemográficas. El análisis exploratorio sugirió una estructura de un factor para ambas subescalas. Los encuestados en el Estudio 2 fueron 262 profesores universitarios (edad media $=41.80 ; D E=9.81 ; 50,8 \%$ hombres). El análisis factorial confirmatorio sugirió la adecuación de la estructura de seis factores teóricamente propuesta para ambas subescalas después de la comparación con el modelo alternativo de factor único. El IPCSSProfesor presentó índices de confiabilidad satisfactorios y está indicado para la aplicabilidad en docentes de diferentes sectores con el fin de comprender sus fortalezas personales.

Palabras clave: fortalezas personales; virtudes; psicología positiva; escala; profesores 
Resumo: Este estudo teve como objetivo apresentar o desenvolvimento e evidências psicométricas da Escala de Importância e Percepção de Forças de Caráter (EIPFC)-versão para Professores. Dois estudos quantitativos foram conduzidos. O Estudo 1 contou com 214 professores universitários (media de idade $=39,21 ; D P=9,77 ; 55,6 \%$ mulheres), que responderam ao EIPFC- Professores e perguntas sociodemográficas. Análises exploratórias sugeriram uma estrutura unifatorial para ambas as subescalas. O Estudo 2 contou com 262 professores universitários (media de idade = 41,$80 ; D P=9,81 ; 50,8 \%$ homens). Análises confirmatórias sugeriram a adequação da estrutura de seis fatores teoricamente proposta para ambas as subescalas, após comparação com o modelo alternativo unifatorial. A EIPFC- Professores apresentou índices satisfatórios de confiabilidade e pode ser aplicada em docentes de diferentes setores, de forma a compreender suas forças de caráter.

Palavras-chave: forças de caráter; virtudes; psicologia positive; escala, docentes

Received: 02/12/2020

Accepted: 02/09/2021

How to cite:

Martins Guerra, V., Alves Freires, L., Lourenço Cintra, C., Bastos Cacciari, M., \& Ferreira Vieira Castello, N. (2021). Importance and Perception of the Character Strengths Scale: psychometric evidence in professors. Ciencias Psicológicas, 15(1), e-2102. doi: ttps://doi.org/10.22235/cp.v15i1.2102

Correspondence: Valeschka Martins Guerra. Universidade Federal do Espírito Santo, Brazil E-mail: valeschka.guerra@ufes.br

Peterson and Seligman (2004) proposed a classification of the main virtues acknowledged by most of the psychological, philosophical and religious approaches. The virtues that comprise this classification are universally recognized as examples of moral excellence, which can be achieved by cultivating specific abilities -the character strengths- which, in turn, can be exercised and improved to achieve the corresponding virtues (Peterson \& Seligman, 2004).

In this sense, character strengths (CS) can be considered expressions of these virtues. They are measurable and expressed through one's thoughts, feelings and behaviors, and may vary during a lifetime, as they are influenced by different contexts. According to Peterson and Seligman (2004), they can be organized into six groups: 1) Wisdom and Knowledge, expressed and exercised by strengths of creativity, curiosity, open-mindedness and love of learning; 2) Courage, which comprises strengths of bravery, persistence, integrity and zest; 3) Humanity, gathering strengths of love, kindness and social intelligence; 4) Justice, expressed and exercised by citizenship, fairness and leadership; 5) Temperance, expressed and exercised by the strengths of forgiveness, humility, prudence and self-regulation; and 6) Transcendence, comprising strengths of appreciation of beauty, gratitude, hope, humor and spirituality.

\section{Existing instruments}

The main instrument devised to measure the 24 CS was the VIA Survey Inventory of Strengths (VIA-IS) (Peterson \& Seligman, 2004). This assessment consists of 240 items presented on a five-point scale (ranging from very much unlike me to very much like me), with ten items to evaluate each theoretically proposed CS.

The measurement of CS determined the empirical evidence of its universal nature (Park, Peterson, \& Seligman, 2006). High rates of agreement, desirability and strength development were observed in remote cultures such as villages in Kenya and Greenland, as well as in large countries like the United States (Biswas-Diener, 2006). Moreover, CS were remarkably similar in 75 
countries, represented by more than one million participants with at least 150 respondents in each country (McGrath, 2015).

For McGrath (2017), the association between virtues and CS proposed in the original classification was determined more theoretically and intuitively than in empirical terms. The author therefore proposed a version of the instrument with 192 items, identifying the best ones in terms of good statistical parameters. Other reduced versions were also proposed: the VIA-120, developed by taking the five items that presented the highest correlations among items for each scale, and the VIA-Brief, which presents a single item per CS, emphasizing the six theoretically proposed virtues as second-order factors (VIA Institute of Character, 2018).

In addition to these instruments, others were proposed by different researchers: the Signature Strengths Survey (SSS); the Global Assessment of Character Strengths (GACS-72) and its reduced version, also encompassing 24 items (McGrath, 2017). In Brazil, in addition to the adaptation of the original VIA-IS (Seibel, DeSousa \& Koller, 2015), an instrument called Character Strengths Scale was developed by Noronha e Barbosa (2016) comprising 71 items.

In general, for the various instruments proposed, the six virtues from the original classification have not emerged in the empirical analyses that were conducted until recently. Models with one (van Eeden, Wissing, Dreyer, Park, \& Peterson, 2008), two (Ng, Cao, Marsh, Tay \& Seligman, 2016) and three factors (McGrath, 2015) were also noted. In Brazil, the adaptation conducted by Seibel et al. (2015) identified that different methods of analysis could lead to different factor solutions with one, three or four factors. The instrument developed by Noronha and Barbosa (2016) also found a one-factor solution. However, a recent publication by Noronha and Batista (2020) has found the six-factor solution (for comparisons of previous studies, refer to McGrath, 2014, and Seibel et al., 2015).

Despite the large number of studies carried out with the construct, the fact that the size of an instrument can be a major deterrent for researchers who seek to associate CS with other variables must be considered. Thus, the importance of developing shorter instruments that evaluate the strengths with individual items is evident. McGrath (2017) reports that different 24-item versions have already been developed and presented in literature (Solano \& Cosentino, 2018; Vanhove, Harms, \& DeSimone, 2016).

In addition to size, the existing instruments generally aim at identifying the participant's perception of each strength as a personal characteristic. However, the relevance given by the individual to each strength is not evaluated. How important that particular strength is for the individual as a person or for the development of their work as a professional, also constitutes an essential piece of information for the professional who is using these instruments to carry out particular work.

Several studies have already investigated the presence and emphasis of CS in the workplace (Harzer, Mubashar, \& Dubreuil, 2017; Heintz \& Ruch, 2020; Meyers, Kooij, Kroon, de Reuver, \& van Woerkom, 2020; Money, Hillenbrand \& Camara, 2009). A research conducted with managers of public and private sector organizations showed that some work demands require the use of specific strengths much less (ex.: humor, spirituality) or more (ex.: self-control, leadership) than what is natural for the individuals (Money et al., 2009).

Perceived organizational support for using CS is associated with higher levels of wellbeing and performance (Meyers et al., 2020). Presenting this support, especially to younger employees, makes them feel valued for their qualities, motivates them and helps them to build the belief in their own abilities.

The congruence between CS and work activities are important for job satisfaction, engagement and meaning, regardless of which CS are used (Harzer et al., 2017). The association of CS and job satisfaction was observed to vary according to the occupational group studied (Heintz \& Ruch, 2020). Job satisfaction for teachers is more strongly associated with zest, hope, 
love, teamwork, leadership and gratitude with different patterns observed for other groups investigated.

Only few studies investigated CS in the educational setting with teachers as participants. A study with Korean special education teachers considered which virtues were perceived as associated with teaching efficacy and found the virtues of humanity and temperance as more strongly associated (Lim \& Kim, 2014). A qualitative study conducted in Brazil investigated what characteristics would be required to be a good professor and fulfill one's academic role (Cacciari, Guerra, Martins-Silva, Cintra \& Castello, 2017). The authors observed that teachers considered the virtues of wisdom, temperance and justice as important for the development of their work. And a study conducted in Slovenia with primary school teachers reported that the highest strengths observed were fairness, kindness, integrity, and love (Gradisek, 2012).

Therefore, this article aims to adapt the classification of CS presenting the development of the Importance and Perception of Character Strengths Scale (IPCSS). The instrument proposes to evaluate not only the individual's perception of their own strengths but also how important each strength is to their work. Understanding the relationship between the perception of themselves as individuals and the importance of what strengths are demanded at their occupational setting can help to explain the association of CS and well-being in the workplace.

College professors were chosen as the focal point for the development of the instrument due to the impact of work in their lives, with considerable implications. An increase in workrelated stress has been observed for some time in higher education institutions. One of the main consequences registered in the literature is a higher level of burnout, affecting the teachers physical and mental health, their work engagement and students' outcomes (Rocha, Jesus, Marzuale, Henriques, Marôco, \& Campos, 2020).

Stressful factors identified were excessive workload, work pressure, low pay, job tasks, low social recognition, lack of resources, as well as family stressors and lack of support (Duke et al., 2019; Rocha et al., 2020; Sabagh, Hall \& Saroyan, 2018). In consequence, the level of burnout has a direct effect in work engagement and commitment, ill health and depression (Sabagh et al., 2018).

Although studies in general emphasize the negative aspects of teaching, such as burnout, research has begun to include its positive aspects. In Brazil, Nassif, Hanashiro and Torres (2010) analyzed the perception of university professors regarding the skills required for teaching, emphasizing the fundamental role of professors in the success or failure of educational processes. Results showed that participants mainly valued teachers who were successful in promoting students' autonomy and consolidating their learning process. However, authors suggest that broader reflection is required regarding the skills of a good professor and how they can be developed in a way that directly influences the qualification of students who are able to meet the demands of the job market.

In a study conducted with 581 university professors, their perceived competence mediated the relationship between research and department support with teaching satisfaction, whereas their perceived autonomy mediated the relationship between teaching satisfaction and all types of support (including chair, administrative, research, among others). In other words, the existence of different levels of support for university teachers is not enough to increase their job satisfaction. This is influenced by their perception of their own competence and autonomy in the job (Larson et al., 2019).

Thereby, the use of the CS classification system and their perception and the importance associated with each strength use in their job can provide an innovative means to develop competencies and autonomy, enticing professors to broaden their reflections about beliefs and teaching strategies. In consequence, their perception of person-job fit could increase, with direct effects not only in their own work, but also in their physical and mental health (McGovern \& Miller, 2008). 
Thus, two studies were conducted: Study 1 aims to present the development and exploratory analyses of the IPCSS-Professors and Study 2 presents evidence of the instrument's validity and accuracy, as well as an investigation of the parameters of its items, by applying the Item Response Theory (IRT).

\section{Method}

\section{Study 1}

\section{Respondents}

The sample comprised 214 college professors, of which $55.6 \%$ were women. Respondents' ages ranged from 22 to $65(M=39.21 ; S D=9.77)$. Of the total number, $73.8 \%$ teach in public universities and $37.4 \%$ in private institutions, all of whom have been teaching for an average of 9.6 years $(S D=7.83)$. Geographically, $63.6 \%$ of respondents live in the Southeast region of Brazil, $25.7 \%$ in the Northeast, $5.1 \%$ in the South, $2.8 \%$ in the North and $2.8 \%$ in the Midwest region.

\section{Instruments}

Importance Scale and Perception of Character Strengths-Professors Version (IPCSSProfessors). A set of 24 items were developed based on the 24 CS proposed by Peterson and Seligman (2004). Items included the name of the strength followed by its description (e.g., "Creativity (originality, ingenuity): constantly challenging your mind; thinking of novel and productive ways of dealing with situations or achieving goals; being capable of offering new and adaptive ideas that contribute positively to a situation"). Respondents were required to read each item and subsequently consider: a) how important each one is for a good professor, using a 5-point scale ranging from 1 (Not important at all) to 5 (Very important); and b) how much each item describes them as a professor, with a rating scale ranging from 1 (Does not describe me at all) to 5 (Describes me completely).

Sociodemographic factors. Respondents were required to inform their age, gender, state of residence and type of higher education institution in which they work (public or private).

\section{Procedures}

This research was approved by the Human Research Ethics Committee of the Universidade Federal do Espírito Santo (Registration n. ${ }^{\circ}$ 84473). The IPCSS-Professor was developed under the International Test Commission (ITC, 2010) guidelines. Initially, two of the authors proposed each 12 individual items that grouped the ideas of the CS. Considering the original language of both classification and VIA-IS, these items were presented to two independent translators who translated the items from Portuguese into English to verify their adequacy with the VIA-IS and VIA-Classification items. Subsequently, the items were compared to VIA-Classification by a group of experts who verified that they were semantically equivalent. Finally, semantic validation was conducted with the target population. Ten university professors analyzed the items in terms of sharpness and level of difficulty, suggesting changes to the ones that were either difficult or confusing. No substantial changes were made to the content of the items, nor in the procedures used to answer the scale, and no item was excluded. The final questionnaire was created and made available online in the Google Forms platform. The access link was provided to professors of public and private universities of Brazil via e-mail, institutional subscribers list, labor unions and social networks. On the first page the respondents were presented with a consent form detailing their rights and anonymity. The respondent had to agree to participate before proceeding to answering the questionnaire. Otherwise, a page thanking them for their interest was presented. 


\section{Data analyses}

The data was analyzed through the Factor software, version 10.10.03 (Ferrando \& LorenzoSeva, 2017). An Exploratory Factor Analysis (EFA) was performed using the polychoric matrix and the Robust Diagonally Weighted Least Squares (RDWLS) extraction method (Asparouhov \& Muthen, 2010) with Robust Promin Rotation (Lorenzo-Seva \& Ferrando, 2019). The retention method of choice was the Parallel Analysis (Timmerman \& Lorenzo-Seva, 2011).

The following goodness-of-fit indexes were used: Root Mean Square Error of Aproximation (RMSEA); Comparative Fit Index (CFI); and Tucker-Lewis Index (TLI). The H index was also selected, to investigate if the set of items represent a common factor that could be considered stable in different studies. Adequate values are considered above 0.80 (Ferrando \& Lorenzo-Seva, 2018).

\section{Results and partial discussion}

As the IPCSS-Professors version consists of two scales, the Importance Scale (IS) and Perception Scale (PS), the analyzes were conducted separately.

\section{Exploratory factor analysis - Importance Scale (IS)}

First, sampling adequacy for factor analysis was verified, based on the Kaiser-Meyer-Olkin (KMO) index, which was 0.70, and Bartlett's Sphericity Test, of $\chi^{2}=2350.60, p<.001$, considered satisfactory. The Parallel Analysis (PA) suggested the existence of a one-factor solution. The closeness to unidimensionality assessment (Ferrando \& Lorenzo-Seva, 2018) also suggested the data is essentially unidimensional ( $\mathrm{UniCo}=0.94 ; \mathrm{ECV}=0.84$; and MIREAL $=0.24$ ). The EFA was then performed by fixing the extraction of one-factor.

Results observed factor loadings greater than .40, with an adequate internal consistency index explaining $45 \%$ of the total variance. Factor loadings ranged between .43 (Item 02 Curiosity) and .80 (Item 19 - Forgiveness), as can be observed in the Table 1. 
Table 1.

Exploratory factor analysis of the IPCSS-Professor Version

\begin{tabular}{lcc}
\hline Items & $\begin{array}{c}\text { Importance } \\
\text { Scale }\end{array}$ & $\begin{array}{c}\text { Perception } \\
\text { Scale }\end{array}$ \\
\hline Item 01 - Creativity & .50 & .47 \\
Item 02 - Curiosity & .43 & .55 \\
Item 03 - Open mindedness & .50 & .51 \\
Item 04 - Love of learning & .48 & .43 \\
Item 05 - Perspective & .55 & .57 \\
Item 06 - Bravery & .73 & .67 \\
Item 07 - Persistence & .74 & .61 \\
Item 08 - Integrity & .62 & .64 \\
Item 09 - Vitality & .71 & .68 \\
Item 10 - Love & .75 & .65 \\
Item 11 - Kindness & .78 & .60 \\
Item 12 - Social intelligence & .71 & .49 \\
Item 13 - Citizenship & .61 & .55 \\
Item 14 - Fairness & .65 & .60 \\
Item 15 - Leadership & .70 & .44 \\
Item 16 - Humility & .71 & .56 \\
Item 17 - Prudence & .67 & .49 \\
Item 18 - Self-control & .67 & .58 \\
Item 19 - Forgiveness & .80 & .53 \\
Item 20 - Appreciation of beauty & .70 & .50 \\
Item 21 - Gratitude & .70 & .63 \\
Item 22 - Hope & .78 & .63 \\
Item 23 - Humor & .55 & .40 \\
Item 24 - Spirituality & .61 & .47 \\
\hline McDonald's Omega & .95 & .91 \\
Observed H index (factor stability) & .91 & .92 \\
\hline
\end{tabular}

Additionally, goodness-of-fit indexes for the exploratory structure were RMSEA $=0.052$ $(0.032-0.056) ; \mathrm{CFI}=0.98$; and $\mathrm{TFI}=0.98$. The parameters related to the PS can be found below.

\section{Exploratory factor analysis - Perception Scale (PS)}

As with IS, sampling adequacy for factor analysis presented adequate $\mathrm{KMO}$ index $=0.82$ and Bartlett's Sphericity Test $\chi^{2}=2253.60, p<.001$. Subsequently, PA also suggested the existence of one PS factor. The closeness to unidimensionality assessment (Ferrando \& LorenzoSeva, 2018) also suggested the data is unidimensional (UniCo $=0.96 ; \mathrm{ECV}=0.83$; and MIREAL $=0.21$ ). EFA was then performed by requesting one-factor. Results indicated that the one-factor solution accounts for $33 \%$ of variance and presents an adequate internal consistency index. Factor loadings ranging from 0.40 (Item 23 - Humor) to 0.68 (Item 09 - Vitality) were observed (see Table 1). Additionally, goodness-of-fit indexes for the exploratory structure were RMSEA $=0.057$ $(0.031-0.082) ; \mathrm{CFI}=0.96$; and $\mathrm{TFI}=0.96$. 
These results corroborate with previous findings that have detected one-factor solutions when using the VIA Survey (van Eeden et al., 2008) as main instrument. Regarding the Brazilian adaptation of VIA-IS (Seibel et al., 2015) and the development of the Character Strengths Scale (Noronha \& Barbosa, 2016), both studies observed one-factor structures, suggesting that the different character strengths seem to present a strong link in Brazil. To confirm this empirical result in comparison to the six-factor proposal, Study 2 will present the items' psychometric evidence and parameters.

\section{Study 2}

\section{Method}

\section{Respondents}

Respondents in this study consisted of 262 college professors, of which $50.8 \%$ were men. The respondents' ages ranged from 25 to 65 (mean $=41.8, S D=9.81$ ). $86 \%$ of the total number teach in public universities and $14 \%$ in private institutions, all of whom have been teaching for an average of 12.13 years $(S D=9.78)$. Regarding geographic location, $74 \%$ of respondents live in the Southeast region, $13 \%$ in the Northeast, $9 \%$ in the North, $2 \%$ in the South and $1.6 \%$ in the Midwest.

\section{Instruments}

The same questionnaire from Study 1 was used, comprising the IPCSS-Professor and sociodemographic questions.

\section{Procedures}

The same procedures of Study 1 were used.

\section{Data analysis}

The R software (R Development Core Team, 2012) was used for data analysis. Initially, a Confirmatory Factor Analysis (CFA) was performed using the Lavaan statistical package (Rosseel, 2012), as well as adopting the Robust Maximum Likelihood (MLR) as input to estimate the covariance matrix. In relation to the goodness-of-fit indexes of the confirmatory model, the criteria and indexes established in literature (Hair, Black, Babin \& Anderson, 2014) were: (a) Chi-square ratio by degrees of freedom of the model $\left(\chi^{2} / g l\right)$; (b) Goodness-of-Fit Index (GFI) and Adjusted Goodness-of-Fit Index (AGFI); (c) Comparative Fit Index (CFI); and (d) Root-Mean-Square Error of Approximation (RMSEA), considering a $90 \%$ Confidence Interval $(90 \% \mathrm{CI}$ ).

In addition, to verify the validity of convergent measures, the average variance extracted (AVE) was investigated, which indicates how much the construct explains the set of items. Regarding the internal consistency index, the Composite Reliability (CR) was calculated (Škerlavaj \& Dimovski, 2009). Finally, the individual parameters for the items of both parts of the scale (Importance and Perception) were evaluated, based on the Samejima's Graded Response model (1969), using the Mirt package (Chalmers, 2012).

\section{Results}

\section{Confirmatory factor analysis - Importance Scale (IS)}

As previously indicated, a CFA was performed to investigate the adequacy of the six-factor model (Peterson \& Seligman, 2004) for the IPCSS-Professor IS, comparing it to the empirical onefactor model. According to results, it was observed that the six-factor model for the importance of CS presented satisfactory fit indexes: $\chi^{2} / g l=2.28$, GFI $=0.99$, AGFI $=0.99$, CFI $=0.91$ and 
RMSEA $=0.07$ (0.062-0.078). All factor weights (lambdas) were statistically different from zero $(\lambda \neq 0 ; z>1.96, p<0.05)$. The one-factor alternative model was also tested to confront the theoretical six-factor model; however, it was less adjusted $\left(\chi^{2} / g l=3.37, \mathrm{CFI}=0.79\right)$. Moreover, all dimensions presented CC indexes higher than 0.60 , but only the Humanity and Transcendence dimensions reached 0.50 indexes in the AVE, as shown in Table 2. The corresponding factor structure can be seen in Figure 1.

Table 2.

Lambdas, Composite Reliability and Average Variance Extracted from IPCSS-Professor

\begin{tabular}{|c|c|c|c|c|c|c|c|c|c|}
\hline \multicolumn{5}{|c|}{ Importance } & \multicolumn{5}{|c|}{ Perception } \\
\hline \multirow{6}{*}{ WIS } & & $\lambda$ & $C R$ & $A V E$ & \multirow{6}{*}{ WIS } & & $\lambda$ & $C R$ & $A V E$ \\
\hline & Item 1 & 0.55 & \multirow{5}{*}{0.74} & \multirow{5}{*}{0.36} & & Item 1 & 0.51 & \multirow{5}{*}{0.69} & \multirow{5}{*}{0.31} \\
\hline & Item 2 & 0.68 & & & & Item 2 & 0.55 & & \\
\hline & Item 3 & 0.64 & & & & Item 3 & 0.58 & & \\
\hline & Item 4 & 0.53 & & & & Item 4 & 0.47 & & \\
\hline & Item 5 & 0.61 & & & & Item 5 & 0.68 & & \\
\hline \multirow{4}{*}{$\mathrm{COU}$} & Item 6 & 0.72 & \multirow{4}{*}{0.75} & \multirow{4}{*}{0.43} & \multirow{4}{*}{$\mathrm{COU}$} & Item 6 & 0.65 & \multirow{4}{*}{0.68} & \multirow{4}{*}{0.35} \\
\hline & Item 7 & 0.70 & & & & Item 7 & 0.59 & & \\
\hline & Item 8 & 0.54 & & & & Item 8 & 0.52 & & \\
\hline & Item 9 & 0.67 & & & & Item 9 & 0.61 & & \\
\hline \multirow{3}{*}{ HUM } & Item 10 & 0.72 & \multirow{3}{*}{0.75} & \multirow{3}{*}{0.50} & \multirow{3}{*}{ HUM } & Item 10 & 0.72 & \multirow{3}{*}{0.67} & \multirow{3}{*}{0.41} \\
\hline & Item 11 & 0.77 & & & & Item 11 & 0.67 & & \\
\hline & Item 12 & 0.63 & & & & Item 12 & 0.53 & & \\
\hline \multirow{3}{*}{ JUS } & Item 13 & 0.63 & \multirow{3}{*}{0.67} & \multirow{3}{*}{0.40} & \multirow{3}{*}{ JUS } & Item 13 & 0.62 & \multirow{3}{*}{0.61} & \multirow{3}{*}{0.34} \\
\hline & Item 14 & 0.61 & & & & Item 14 & 0.61 & & \\
\hline & Item 15 & 0.67 & & & & Item 15 & 0.53 & & \\
\hline \multirow{4}{*}{ TEM } & Item 16 & 0.70 & \multirow{4}{*}{0.78} & \multirow{4}{*}{0.48} & \multirow{4}{*}{ TEM } & Item 16 & 0.63 & \multirow{4}{*}{0.71} & \\
\hline & Item 17 & 0.67 & & & & Item 17 & 0.65 & & 039 \\
\hline & Item 18 & 0.66 & & & & Item 18 & 0.62 & & 0.39 \\
\hline & Item 19 & 0.75 & & & & Item 19 & 0.60 & & \\
\hline & Item 20 & 0.66 & & & & Item 20 & 0.53 & & \\
\hline & Item 21 & 0.82 & & & & Item 21 & 0.69 & & \\
\hline TRA & Item 22 & 0.75 & 0.83 & 0.50 & TRA & Item 22 & 0.63 & 0.70 & 0.32 \\
\hline & Item 23 & 0.59 & & & & Item 23 & 0.45 & & \\
\hline & Item 24 & 0.71 & & & & Item 24 & 0.54 & & \\
\hline
\end{tabular}

Note . WIS $=$ Wisdom. COU $=$ Courage. HUM $=$ Humanity. JUS = Justice. TEM = Temperance. TRA = Transcendence. 


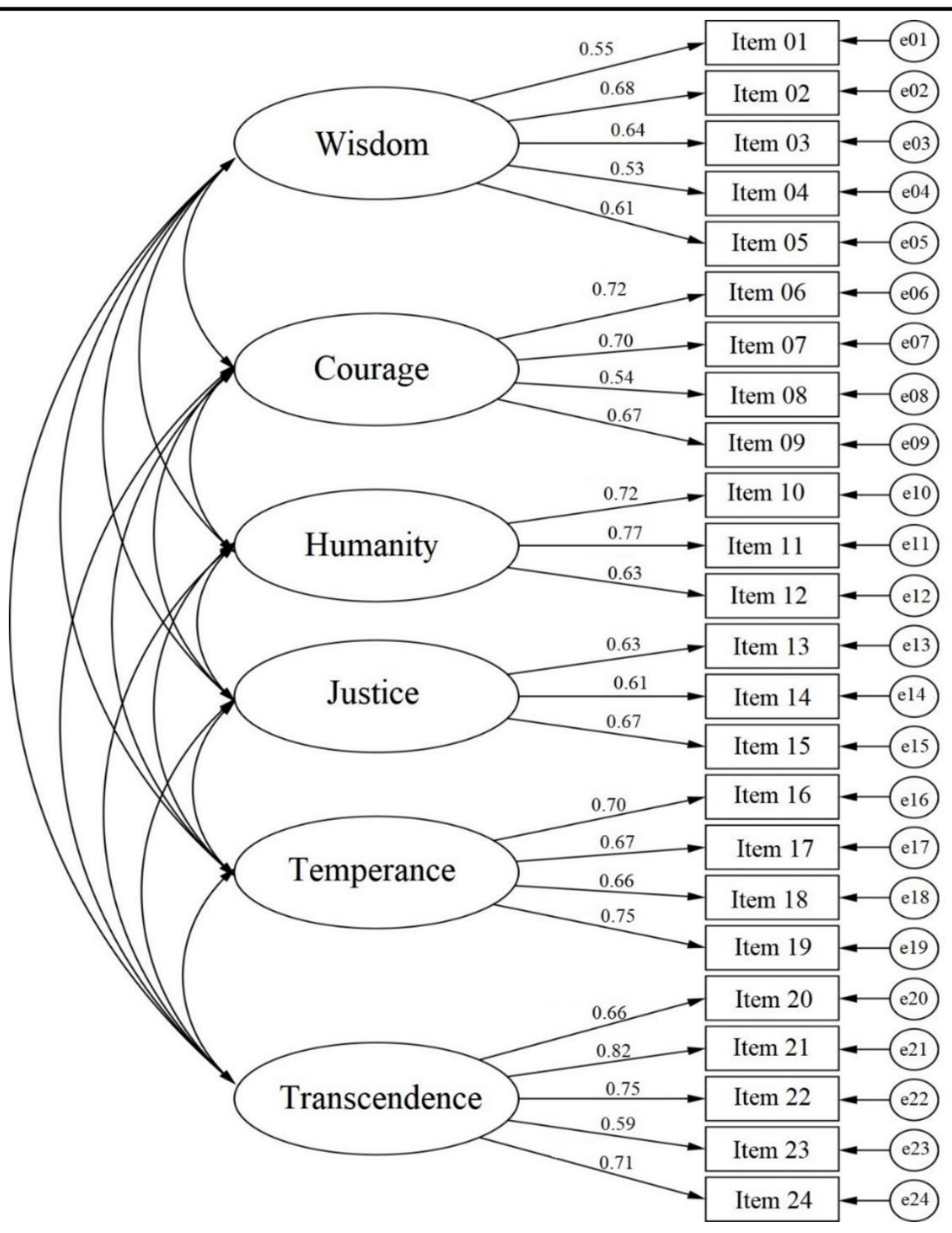

Figure 1. Factor structure of the IPCSS-Professor's Importance Scale. 


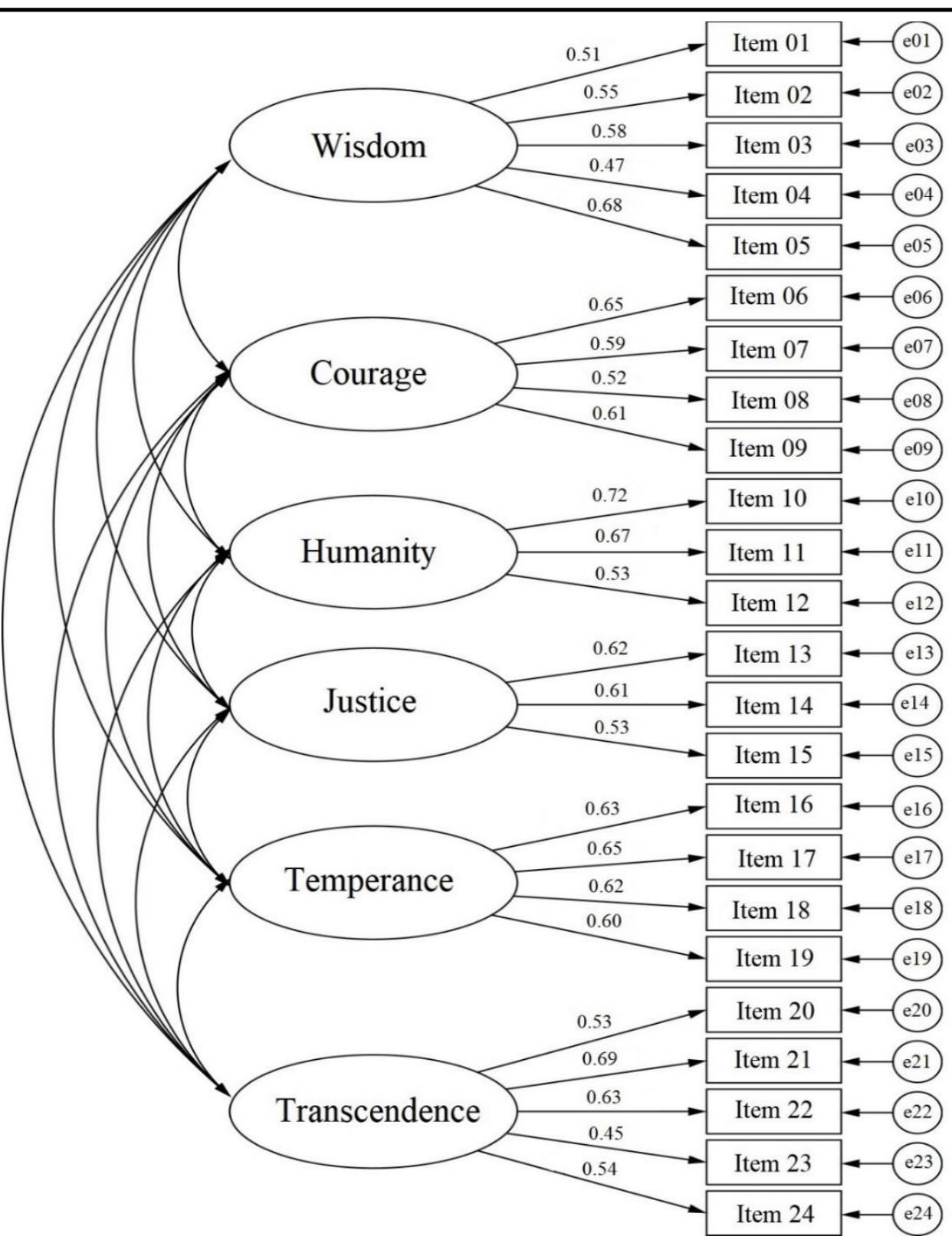

Figure 2. Factor structure of the IPCSS-Professors Perception Scale.

Regarding the adjustment indexes of the IPCSS-Professors PS, the six-factor model was equally adequate: $\chi^{2} / g l=1.93, \mathrm{GFI}=0.99, \mathrm{AGFI}=0.99, \mathrm{CFI}=0.89$ and RMSEA $=0.06(0.051-$ 0.068). Moreover, all factor weights (lambdas) were statistically different from zero $(\lambda \neq 0 ; z>$ $1.96, p<.05)$. The one-factor alternative model was tested to confront the six-factor model; however, it was less adjusted $\left(\chi^{2} / \mathrm{gl}=2.34, \mathrm{CFI}=0.82\right)$ for PS as well. Regarding the CR indexes, all dimensions exceed 0.60 values. On the other hand, none of the dimensions reached a 0.50 minimum index, with respect to AVE, as presented in Table 2. The corresponding factor structure can be seen in Figure 2. 


\section{Parameters of IPCSS-Professors items}

Once factor structures for both parts of the IPCSS-Professors were confirmed, the investigation of the parameters of its items continued, based on the Item Response Theory (IRT); more specifically, in Samejima's Graded Response Model (1969). Analyses for the items of each factor of the two parts of the instrument were conducted, seeking its parameters of discrimination and difficulty.

Initially, in relation to IS, all items for each dimension were considered jointly and they presented discrimination rates ranging from 2.10 (Wisdom) to 2.46 (Humanity). Regarding difficulty parameters, in general $\left(b_{1}-b_{4}\right)$, data indicates that all six dimensions require a small amount of the latent trait to be endorsed (Wisdom $=-2.34$, Courage $=-2.00$, Humanity $=-1.67$, Justice $=-2.12$, Temperance $=-1.75$, Transcendence $=-1.29$ ). Regarding the Test Information Curve, it was observed that all IS dimensions were informative in the -4.00 to $\approx 2.00$ latent interval. In summary, dimensions tended to be more informative in the middle portion of the latent trait.

Regarding PS, all items for each dimension were considered jointly and showed discrimination rates ranging from 1.50 (Wisdom) to 1.92 (Humanity). In terms of difficulty parameters, in general $\left(b_{1}-b_{4}\right)$, data indicates that all six dimensions require a small amount of the latent trait to be endorsed (Wisdom $=-1.77$, Courage $=-1.55$, Humanity $=-1.65$, Justice $=-$ 1.91, Temperance $=-1.46$, Transcendence $=-1.44$ ). In regard to the Test Information Curve, it was observed that all PS dimensions were informative in the -4.00 to $\approx 2.10$ latent interval. Thus, dimensions also presented a tendency to be more informative in the middle portion of the latent trait.

\section{General discussion}

The objective of this study was to devise an instrument based on the classification of CS that evaluates not only perception but also the importance of these strengths for university professors, investigating its factor structure and internal consistency. The theoretically proposed six-factor structure (Peterson \& Seligman, 2004) for the 24 CS classification was tested using exploratory and confirmatory statistical procedures and confronted with an alternative one-factor model. In the analyses performed, the six-factor structure was proven to be empirically adjusted (Hair et al., 2014) and the IPCSS-Professors presented internal consistency indexes which were considered satisfactory for research purposes (Škerlavaj \& Dimovski, 2009). Considering the results above, it is believed that the objectives have been achieved.

Regarding the psychometric parameters of the items in the two IPCSS-Professors subscales investigated via IRT, the results indicated adequate discrimination rates for all instrument dimensions, for both IS and PS. In terms of the parameters of difficulty, Wisdom, Justice and Courage presented the lowest difficulty rates on the IS. As for the PS, the dimensions with the lowest levels of difficulty were Justice, Wisdom and Humanity. However, it is important to note that, in general, all the dimensions of the two parts of the instrument required a low trait magnitude in order to be accepted or endorsed. This is mainly due to the construct's nature, i.e., the CS represent positive traits that differentiate individuals and are therefore desirable attributes (Peterson \& Seligman, 2004).

Due to the differences that were observed among factor models considered in literature and those that confirm the original classification with respect to the structure of the instrument, it is important to consider possible limitations of the results presented in these studies. It is crucial to emphasize that the samples are hardly representative of the global Brazilian population: the participants were university professors, who mostly reside in the Southeast region and teach in public universities. These characteristics can alter the structures of the analyzed instruments, since the organization of factors will depend on how the participants perceive and respond to the items, associating them specifically to a given group and/or culture. Furthermore, only the alternative 
one-factor model found in Study 1 was considered for comparison purposes. Further investigation is needed to test such structure in different Brazilian groups. The six-factor structure that was tested here corroborates the theoretical proposal of Peterson and Seligman (2004), as well as other studies using multifactor structures (McGrath, 2014; Noronha \& Batista, 2020).

Due to the characteristics of the sample, as well as the chosen profession for instrument testing, the findings may pertain specifically to such group. Additionally, an important limitation must be addressed in future studies: the lack of testing for the convergent validity of the instrument, which provides an essential information regarding the quality of the new instrument. Also, factorial invariance should be tested with different samples and subsamples.

Despite such limitations, the dimensions observed reflect the CS attributed as important to the profession, as well as how much the studied group perceives that it possesses such strengths. Such results may suggest an organization structure of both importance and perception of strengths that must be investigated in other samples with different characteristics.

In this sense, future studies must explore the possible contributions that this instrument can bring in terms of new studies and practical applications. A more comprehensive sample of professors from all over Brazil would be useful to identify the profile of CS importance and perception for Brazilian professors. Such nation-wide study must balance not only the country's regions, but also professors from both public and private institutions, as well as different teaching segments.

Further research could investigate the relationship of the importance and perception of CS with job satisfaction, work engagement and the support for different activities in the educational setting (Harzer et al., 2017). As supporting the use of strengths is associated with well-being (Meyers et al., 2020), identifying which strengths could be exercised and used to address the stressful factors of the workplace could improve teachers' mental health. Also, the use of CS alongside with training specific teaching behaviors could contribute for teachers' self-knowledge and teaching efficacy, as proposed by McGovern and Miller (2008).

Moreover, studies are suggested to evaluate the contribution of the scale to the understanding of character strengths in other professions or samples with different characteristics. The instrument was developed in a way to allow variation in the instructions according to the desired sample characteristics, without changing the items.

Regarding possible contributions of this instrument to literature, in addition to its adaptation and use for different professions and contexts, we must highlight that its reduced size facilitates the development of research projects and associations with other instruments. Furthermore, our scale aims at correcting some of the problems identified in literature surrounding specific CS. Such problems -summarized by McGrath (2017)- suggest, for example, that VIA-IS items that measure the spirituality strength presented specific characteristics of religious denominations that are unsuitable for the more general concept of spirituality. IPCSS-Professors presents an individual item on spirituality aligned with the current perspective adopted by the VIA Institute of Character, which mostly concerns the perception of a meaning to life and being part of something greater than oneself. 


\section{References}

Asparouhov, T., \& Muthen, B. (2010). Simple second order chi-square correction. Unpublished manuscript. Available at https://www.statmodel.com/download/WLSMV_new_chi21.pdf

Biswas-Diener, R. (2006). From the Equator to the North Pole: A study of character strengths. Journal of Happiness Studies, 7, 293-310. https://doi.org/10.1007/s10902-005-3646-8

Cacciari, M. B., Guerra, V. M., Martins-Silva, P. O., Cintra, C. L., \& Castello, N. F. V. (2017). Percepções de professores universitários brasileiros sobre as virtudes mais valorizadas no exercício da docência. Psicologia Escolar e Educacional, 21(2), 313-322. https://doi.org/10.1590/2175-3539/2017/02121121

Chalmers, R. P. (2012). mirt: A Multidimensional Item Response Theory Package for the R $\begin{array}{lllll}\text { Environment. Journal of Statistical Software, } & \text { 48(6), }\end{array}$ https://doi.org/10.18637/jss.v048.i06

Duke, N. N., Gross, A., Moran, A., Hodsdon, J., Demirel, N., Osterholm, E., Sunni, M. \& Pitt, M. B. (2019). Institutional Factors Associated with Burnout Among Assistant Professors. Teaching and Learning in Medicine, 32(1), 61-70. https://doi.org/10.1080/10401334.2019.1638263

Ferrando, P.J., \& Lorenzo-Seva, U. (2017). Program FACTOR at 10: origins, development and future directions. Psicothema, 29(2), 236-241. https://doi.org/10.7334/psicothema2016.304

Ferrando, P. J., \& Lorenzo-Seva U. (2018). Assessing the quality and appropriateness of factor solutions and factor score estimates in exploratory item factor analysis. Educational and Psychological Measurement, 78, 762-780. https://doi.org/10.1177/0013164417719308

Gradisek, P. (2012). Character Strengths and Life Satisfaction of Slovenian In-service and Preservice Teachers. Center for Educational Policy Studies Journal, 2(3), 167-180.

Hair, J. R. Jr., Black, W. C., Babin, B. J., \& Anderson, R. E. (2014). Multivariate Data Analysis (7th ed.). Harlow: Pearson Education Limited.

Harzer C., Mubashar T., \& Dubreuil P. (2017). Character strengths and strength-related personjob fit as predictors of work-related wellbeing, job performance, and workplace deviance. Wirtschaftspsychologie, 19(3), 23-38.

Heintz, S. \& Ruch, W. (2020). Character Strengths and Job Satisfaction: Differential Relationships Across Occupational Groups and Adulthood. Applied Research in Quality of Life, 15, 503527. https://doi.org/10.1007/s11482-018-9691-3

International Test Commission. (2010). Guidelines for Translating and Adapting Tests. Retrieved from: http://www.intestcom.org

Larson, L. M., Seipel, M. T., Shelley, M. C., Gahn, S. W., Ko, S. Y., Shenkenfelder, M., Rover, D. T., Schmittmann, B., \& Heitmann, M. M. (2019). The Academic Environment and Faculty Well-Being: The Role of Psychological Needs. Journal of Career Assessment, 27(1), 167-182. https://doi.org/10.1177/1069072717748667

Lim, Y-J. \& Kim, M-N. (2014). Relation of character strengths to personal teaching efficacy in Korean special education teachers. International Journal of Special Education, 29(2), 5358.

Lorenzo-Seva, U., \& Ferrando, P.J. (2019). Robust Promin: a method for diagonally weighted factor rotation. LIBERABIT, Revista Peruana de Psicología, 25, 99-106. https://doi.org/10.24265/liberabit.2019.v25n1.08

McGovern, T. V., \& Miller, S. L. (2008). Integrating teacher behaviors with character strengths and virtues for faculty development. Teaching of Psychology, 35(4), 278-285. https://doi.org/10.1080/00986280802374609

McGrath, R. E. (2014). Scale- and Item-Level Factor Analyses of the VIA Inventory of Strengths. Assessment,21(1), 4-14. https://doi.org/10.1177/1073191112450612 
McGrath, R. E. (2015): Character strengths in 75 nations: An update. The Journal of Positive Psychology, 10(1), 41-52. https://doi.org/10.1080/17439760.2014.888580

McGrath, R. E. (2017). Technical report: The VIA Assessment Suite for Adults: Development and initial evaluation. Cincinnati, OH: VIA Institute on Character.

Meyers, M. C., Kooij,D., Kroon, B., de Reuver, R., \& van Woerkom, M. (2020). Organizational Support for Strengths Use, Work Engagement, and Contextual Performance: The Moderating Role of Age. Applied Research in Quality of Life, 15, 485-502. https://doi.org/10.1007/s11482-018-9702-4

Money, K., Hillenbrand, C., \& Da Camara, N. (2009). Putting Positive Psychology to Work in Organisations. Journal of General Management, 34(3), 31-36. https://doi.org/10.1177/030630700903400302

Nassif, V., Hanashiro, D. M., \& Torres, R. (2010) Fatores que influenciam na percepção das competências para o exercício da docência. Revista Brasileira de Educação, 15(44), 364379. https://doi.org/10.1590/S1413-24782010000200012

Ng, V., Cao, M., Marsh, H. W., Tay, L., \& Seligman, M. P. (2017). The factor structure of the Values in Action Inventory of Strengths (VIA-IS): An item-level exploratory structural equation modeling (ESEM) bifactor analysis. Psychological Assessment, 29(8), 10531058. https://doi.org/10.1037/pas0000396

Noronha, A. P. P. \& Barbosa, A. J. G. (2016). Forças e virtudes: Escala de Forças de Caráter. Em: C. Hutz. (Org.). Avaliação em Psicologia Positiva (pp. 21-43). São Paulo: Hogrefe CETEP.

Noronha, A. P. P., \& Batista, H. H. V. (2020). Analysis of the internal structure of the Character $\begin{array}{llll}\text { Strengths } \quad \text { Scale. } & \text { Ciencias } & \text { Psicológicas, }\end{array}$ https://doi.org/10.22235/cp.v14i1.2150

Park, N., Peterson, C., \& Seligman, M. E. (2006). Character strengths in fifty-four nations and the fifty US states. The Journal of Positive Psychology, 1(3), 118-129. https://doi.org/10.1080/17439760600619567

Peterson, C., \& Seligman, M. E. (2004). Character strengths and virtues: A handbook and classification. Oxford University Press.

$\mathrm{R}$ Development Core Team (2012). R: A language and environment for statistical computing. $\mathrm{R}$ Foundation for Statistical Computing.

Rocha, F. L. R., Jesus, L. C., Marzuale, M. H. P., Henriques, S. H., Marôco, J., \& Campos, J. A. D. B. (2020). Burnout syndrome in university professors and academic staff members: psychometric properties of the Copenhagen Burnout Inventory-Brazilian version. Psicologia: Reflexão e Crítica, 33(11), https://doi.org/10.1186/s41155-020-00151-y

Rosseel, Y. (2012). lavaan: An R Package for Structural Equation Modeling. Journal of Statistical Software, 48(2), 1-36. https://doi.org/10.18637/jss.v048.i02

Sabagh, Z., Hall, N. C. \& Saroyan, A. (2018) Antecedents, correlates and consequences of faculty $\begin{array}{llll}\text { burnout. } & \text { Educational } & \text { Research, } & \text { 131-156. }\end{array}$ https://doi.org/10.1080/00131881.2018.1461573

Samejima, F. (1969). Estimation of Latent Ability Using a Response Pattern of Graded Scores (Psychometric Monograph No. 17). Richmond, VA: Psychometric Society. Retrieved from: http://www.psychometrika.org/journal/online/MN17.pdf

Seibel, B. L., DeSousa, D., \& Koller, S. H. (2015). Adaptação brasileira e estrutura fatorial da Escala 240-item VIA Inventory of Strengths. Psico-USF, 20(3), 371-383. https://doi.org/10.1590/1413-82712015200301

Škerlavaj, M., \& Dimovski, V. (2009). Organizational learning and performance in two national cultures: A multi-group structural equation modeling approach. In W. R. King (Ed.), Knowledge management and organizational learning (Vol. 4, pp. 321-366). New York, NY: Springer. https://doi.org/10.1007/978-1-4419-0011-1_19 
Solano, A. \& Cosentino, A. C. (2018). IVyF abreviado —IVyFabre_- análisis psicométrico y de estructura factorial en Argentina. Avances en Psicología Latinoamericana, 36, 619-637. https://doi.org/10.12804/revistas.urosario.edu.co/apl/a.4681

Timmerman, M. E., \& Lorenzo-Seva, U. (2011). Dimensionality Assessment of Ordered Polytomous Items with Parallel Analysis. Psychological Methods, 16, 209-220. https://doi.org/10.1037/a0023353

van Eeden, C., Wissing, M. P., Dreyer, J., Park, N., \& Peterson, C. (2008). Validation of the values in action inventory of strengths for youth among South African learners. Journal of Psychology in Africa, 18(1), 143-154. https://doi.org/10.1080/14330237.2008.10820181

Vanhove, A. J., Harms, P. D., \& DeSimone, J. A. (2016). The Abbreviated Character Strengths Test (ACST): A preliminary assessment of test validity. Journal of Personality Assessment, 98, 536-544. https://doi.org/10.1080/00223891.2016.1148044

VIA Institute of Character (2018). VIA Survey Psychometric Data. Retrieved from: https://www.viacharacter.org/www/VIA-Assessments-Psychometrics

Authors' participation: a) Conception and design of the work; b) Data acquisition; c) Analysis and interpretation of data; d) Writing of the manuscript; e) Critical review of the manuscript.

V. M. G. has contributed in a, b, c, d and e; L. A. F. has contributed in c, d and e; C. L. C has contributed in a, b, c and d; M. B. C. has contributed in a, b, c and d; and N. F. V. C has contributed in $\mathrm{a}, \mathrm{b}, \mathrm{c}$ and $\mathrm{d}$.

Scientific editor in charge: Dra. Cecilia Cracco. 